\title{
ANALISIS ALTMAN Z-SCORE UNTUK MEMPREDIKSI KEBANGKRUTAN PADA BANK PEMERINTAH (BUMN) DI INDONESIA TAHUN 2012-2016
}

\author{
Abdul Kadim ${ }^{1)} \&$ Nardi Sunardi ${ }^{2)}$ \\ 1) dosen Universitas Persada Indonesia YAl, email : sak.kadim@yahoo.com \\ 2) dosen Universitas Pamulang, email : : dosen01030@unpam.ac.id
}

\section{ARTICLES \\ INFORMATION \\ JURNAL SEKURITAS \\ (Saham, Ekonomi, Keuangan dan Investasi ) \\ Vol.1, No.3, Maret 2018 \\ Halaman : $142-156$ \\ C LPPM \& Prodi Manajemen \\ UNVERSITAS PAMULANG \\ ISSN (online) : 2581-2777 \\ ISSN (print) : : 2581-2696}

\section{Keyword :}

perusahaan farmasi, kebangkrutan, altman zscore

JEL. classification :

C31, E50

\section{Contact Author :}

PRODI MANAJEMEN UNPAM

JL.Surya Kencana No.1 Pamulang

Tangerang Selatan - Banten

Telp. (021) 7412566, Fax (021) 7412491 Email:

jurnalfinance.unpam@gmail.com
Penelitian ini bertujuan untuk mengetahui tingkat kebangkrutan perusahaan dengan menggunakan model Altman Z-Score pada Bank Pemerintah (BUMN) dari tahun 2012-2016 yang terdaftar di Bursa Efek Indonesia. Kriteria pengambilan sampel menerbitkan laporan keuangan secara teratur pada tahun 2012 sampai dengan tahun 2016. Hasil penelitian ini menunjukkan bahwa model Z-Score Altman tersebut dapat diimplementasikan dalam mendeteksi kemungkinan terjadinya kebangkrutan pada Bank Pemerintah (BUMN) yang terdaftar di Bursa Efek Indonesia. Adapun saran untuk perusahaan yang masuk dalam dikategorikan rawan bangkrut, harus berhati-hati dalam melakukan pengambilan kebijakan perusahaan serta berusaha untuk terus meningkatkan kinerja perusahaan dan berusaha memanfaatkan aset yang dimilikinya dengan sebaik-baiknya untuk meraih keuntungan yang sebesar-besarnya. Sedangkan perusahaan yang dalam kondisi sehat harus tetap mempertahankan dan meningkatkan kinerjanya dalam menghasilkan laba agar tidak mengalami kebangkrutan.

This research is meant to find out the company bankruptcy level by applying the Altman Z-score model in the goverment bank (BUMN) 2012-2016 which are listed in The Indonesia Stock Exchange. The collected data is in the form of financial reports which consist of loss-profit report and balance sheet from 2012 to 2016. The sample collection criteria publish the financial report regularly from 2012 to 2016 . The result of this research indicates that this Altman Z-score model can be implemented in detecting the possibility of bankruptcy at goverment bank (BUMN) which are listed in the Indonesia Stock Exchange. There are some recommendations for the companies which are categorized into bankruptcy prone should be careful in making company policies and trying to improve the company performance and trying to use their assets carefully in order to achieve the biggest profit. Meanwhile, the company which is in good condition should keep and improve their performance in order to get the earnings to avoid the bankruptcy. 


\section{A. Pendahuluan}

Kebangkrutan perusahaan merupakan salah satu fenomena yang sering terjadi dalam dunia usaha baik dipengaruhi oleh pihak internal maupun eksternal perusahaan. Misalnya terjadi kenaikan biaya bahan baku, biaya upah, biaya listrik atau biaya lainnya tanpa diimbangi dengan kemampuan perusahaan, adanya produk pesaing yang lebih unggul sehingga mempengaruhi penjualan dan ketidakmampuan manajer dalam melakukan manajemen perusahaan.

Kejadian tersebut secara tidak langsung akan berpengaruh terhadap penurunan kinerja perusahaan dan dapat menyebabkan perusahaan mengalami kebangkrutan. Untuk mengantisipasi terjadinya kebangkrutan maka perusahaan harus mempunyai persiapan dini untuk mencegah agar tidak terjadi hal yang tidak diinginkan. Perusahaan diharapkan dapat menilai kondisi perusahaan yang sedang berjalan agar memperoleh gambaran yang lebih jelas mengenai kondisi perusahaan sekarang ini, sehingga dapat mengetahui tindakan apa yang tepat untuk mempertahankan dan memperbaiki kekurangan perusahaan agar dapat bertahan dan bersaing.

Untuk mengantisipasi terjadinya kebangkrutan maka perusahaan harus mempunyai persiapan dini untuk mencegah agar tidak terjadi hal yang tidak diinginkan. Perusahaan diharapkan dapat menilai kondisi perusahaan yang sedang berjalan agar memperoleh gambaran yang lebih jelas mengenai kondisi perusahaan sekarang ini, sehingga dapat mengetahui tindakan apa yang tepat untuk mempertahankan dan memperbaiki kekurangan perusahaan agar dapat bertahan dan bersaing.

Salah satu alat yang digunakan perusahaan untuk menilai kondisi perusahaan adalah laporan keuangan yang dihasilkan setiap periode. Agar perusahaan dapat mengetahui lebih jelas kondisi perusahaan sekarang ini, maka perusahaan dapat membandingkan laporan keuangan yang sekarang dengan laporan keuangan periode sebelumnya. Salah satu model kebangkrutan yang terbukti memberikan banyak manfaat adalah model Z-Score. Model ini dikembangkan oleh Edward I Altman seorang ekonom keuangan.

Model ini merupakan pengembangan dari teknik statistik multiple discriminant yang menggabungkan efek beberapa variabel. Model Altman ini merupakan suatu model analisis keuangan yang telah banyak digunakan di Amerika Serikat.

Analisis kebangkrutan ini sangatlah penting karena dapat menilai indikasi kebangkrutan perusahaan, apakah suatu perusahaan terancam bangkrut atau tidak, dimana bila terjadi kebangkrutan perusahaan dapat merugikan banyak pihak seperti manajer, investor, kreditor, bahkan karyawan tersebut. Berdasarkan hal yang telah disampaikan di atas kemudian peneliti merasa sangat penting untuk dapat melakukan penelitian tentang bagaimanakah indikasi kebangkrutan dengan model altman z-score pada Bank Pemerintah (BUMN) yang terdaftar di Bursa Efek Indonesia dari tahun 20122016 dan apakah model altman z-score dapat digunakan sebagai alat dalam memprediksi kecendrungan kebangkrutan perusahaan. Penelitian ini dilakukan dengan menganalisa kebangkrutan yang menggunakan model Altman Z-Score pada Bank Pemerintah (BUMN) yang terdaftar di Bursa Efek Indonesia dari tahun 2012-2016. Adapun tujuan penelitian ini: (1) Untuk mengetahui indikasi kebangkrutan pada subsektor ogam \& sejenisnya periode 2014 dengan model Altman z-score.; (2) Untuk mengetahui apakah model altman z-score dapat digunakan sebagai alat dalam memprediksi kecendrungan kebangkrutan perusahaan.

Menurut Edward I. Altmarn, dalam penelitiannya tersebut setelah menyeleksi 22 rasio keuangan, altman menentukan lima rasio keuangan yang dapat digunakan untuk mendeteksi kebangkrutan perusahaan beberapa saat sebelum perusahaan tersebut bangkrut. Kelima rasio tersebut terdiri dari : modal kerja terhadap aktiva, laba ditahan terhadap total aktiva, laba sebelum bunga dan pajak terhadap aktiva, nilai pasar modal saham terhadap nilai buku hutang, dan penjualan terhadap aktiva. Analisis tersebut dikenal dengan analisis Z-Score yang dapat memprediksi secara akurat tentang kinerja 
perusahaan, serta kemungkinan kondisi kesehatan keuangan di masa yang akan datang, apakah perusahaan mengalami kebangkrutan, rawan bangkrut, atau dalam keadaan sehat. Hal tersebut sangat membantu bagi para investor dalam menanamkan modalnya, apakah ia akan menjual, membeli, atau bahkan menahan investasinya pada perusahaan yang bersangkutan. Dan bagi para leaders (pemimpin) perusahaan, mereka mempunyai kepentingan untuk dapat menyusun, mempertimbangkan, dan memperbaiki serta mennetukan keputusan yang tepat agar dapat dipertanggung jawabkan kepada para pemegang saham atau investor.

Berdasarkan latar belakang diatas, maka judul penelitian ini adalah "Analisis Altman Z-Score untuk Memprediksi Kebangkrutan pada Bank Pemerintah (BUMN) di Indonesia dari tahun 2012-2016"

\section{B. Perumusan Masalah}

Berdasarkan latar belakang masalah di atas maka masalah yang akan dibahas dan dicari jawabannya dalampenelitian ini adalah :

"Bagaimana potensi kebangkrutan pada Bank Pemerintah (BUMN) yang terdaftar di Bursa Efek Indonesia dari tahun 2012-2016 berdasarkan metode analisis Z - Score?".

\section{Landasan Teori \\ Kebangkrutan}

Perusahaan tidak selalu berjalan sesuai dengan rencana. Pada situasi tertentu, perusahaan mungkin akan mengalami kesulitan keuangan yang ringan seperti mengalami kesulitan likuiditas (tidak bisa membeyar gaji pegawai, bunga utang). Jika tidak diselesaikan dengan benar, kesulitan kecil tersebut bisa berkembang menjadi kesulitan yang lebih besar, dan bisa sampai pada kebangkrutan.

Menurut Hanafi (2008) pengertian kebangkrutan bisa dilihat dari pendekatan aliran dan pendekatan stok. Dengan menggunakan pendekatan stok, perusahaan bisa dinyatakan bangkrut jika total kewajiban melebihi total aktiva. Dengan menggunakan pendekatan aliran, perusahaan akan bangkrut jika tidak bisa menghasilkan aliran kas yang cukup. Dari sudut pandang stok, perusahaan dinyatakan bangkrut meskipun perusahaan masih dapat menghasilkan aliran kas yang cukup, atau mempunyai prospek yang baik dimasa mendatang.

\section{Masalah-Masalah Kebangkrutan}

Masalah yang timbul sehingga dapat mengakibatkan kebangkrutan yaitu, kesulitan keuangan jangka pendek yang berujung menjadi kesulitan yang tidak solvabel. Kesulitan yang tidak solvabel adalah perusahaan mengalami kesulitan dalam membayar hutang karena asset yang terbatas. Kalau tidak solvabel, perusahaan bisa dilikuidasi atau direorganisasi. Likuidasi dipilih apabila nilai likuidasi lebih besar dibandingkan dengan nilai perusahaan. Reorganisasi dipilih kalua perusahaan masih menunujukkan prospek dan dengan demikian nilai perusahaan kalua diteruskan lebih besar dibandingkan nilai perusahaan kalau dilikuidasi.

Empat variable yang menunjukkan perbedaan antara perusahaan yang bangkrut dengan yang tidak bangkrut adalah :

a. Tingkat return (rate of return). Perusahaan yang bangkrut mempunyai tingkat return yang lebih rendah.

b. Penggunaan hutang. Perusahaan yang bangkrut menggunakan hutang yang lebih tinggi.

c. Perlindungan terhadap biaya tetap (Fixed payment coverage). Perusahaan yang bangkrut mempunyai perlindungan terhadap biaya tetap yang lebih kecil. 
d. Fluktuasi return saham Bank Pemerintah (BUMN) yang terdaftar di Bursa Efek Indonesia dari tahun 2012-2016 yang bangkrut mempunyai rata-rata return yang lebih rendah dan mempunyai fluktuasi return saham yang lebih tinggi.

Menurut Foster (1986) terdapat beberapa indikator atau sumber informasi mengenai kemungkinan dari kesulitan keuangan:

1. Analisis arus kas untuk periode sekarang dan yang akan datang.

2. Analisis strategi Bank Pemerintah (BUMN) yang terdaftar di Bursa Efek Indonesia dari tahun 2012-2016 yang mempertimbangkan pesaing potensial, struktur biaya relatif, perluasan rencana dalam industri, kemampuan perusahaan untuk meneruskan kenaikan biaya, kualitas manajemen dan lain sebagainya.

3. Analisis laporan keuangan dari perusahaan serta perbandingannya dengan perusahaan lain. Analisis ini fokus pada suatu variabel keuangan tunggal atau suatu kombinasi dari variabel keuangan.

4. Informasi eksternal seperti return sekuritas dan penilaian obligasi.

\section{Faktor-Faktor Penyebab Kebangkrutan}

Faktor-faktor penyebab kebangkrutan perusahaam menurut Jauch dan Glueck (dalam Adnan, 2000:139) adalah:

\section{Faktor Umum}

\section{a. Sektor ekonomi}

Faktor-faktor penyebab kebangkrutan dari sektor ekonomi adalah gejala inflasi dan deflasi dalam harga barang dan jasa, kebijakan keuangan, suku bunga dan devaluasi atau revaluasi uang dalam hubungannya dengan uang asing serta neraca pembayaran, surplus atau deficit dalam hubungannya dengan perdagangan luar negeri.

\section{b. Sektor sosial}

Faktor sosial sangat berpengaruh terhadap kebangkrutan cenderung pada perubahan gaya hidup masyarakat yang mempengaruhi permintaan terhadap produk dan jasa ataupun cara perusahaan berhubungan dengan karyawan. Faktor sosial yang lain yaitu kerusuhan atau kekacauan yang terjadi di masyarakat.

\section{c. Teknologi}

Penggunaan teknologi informasi juga menyebabkan biaya yang ditanggung perusahaan membengkak terutama untuk pemeliharaan dan implementasi. Pembengkakan terjadi, jika penggunaan teknologi informasi tersebut kurang terencana oleh pihak manajemen, sistemnya tidak terpadu dan para manajer pengguna kurang profesional.

\section{d. Sektor pemerintah}

Pengaruh dari sektor pemerintah berasal dari kebijakan pemerintah terhadap pencabutan subsidi pada perusahaan dan industri, pengenaan tarif ekspor dan impor barang berubah, kebijakan undang-undang baru bagi perbankan atau tenaga kerja dan lain-lain.

\section{Faktor Eksternal Perusahaan}

\section{a. Faktor pelanggan / konsumen}

Perusahaan harus bisa mengidentifikasi sifat konsumen, karena berguna untuk menghindari kehilangan konsumen, juga untuk menciptakan peluang untuk menemukan konsumen baru dan menghindari menurunnya hasil penjualan dan mencegah konsumen berpaling ke pesaing.

\section{b. Faktor kreditur}

Kekuatannya terletak pada pemberian pinjaman dan mendapatkan jangka waktu pengembalian hutang yang tergantung kepercayaan kreditur terhadap likuiditas suatu perusahaan. 


\section{c. Faktor pesaing}

Faktor ini merupakan hal yang harus diperhatikan karena menyangkut perbedaan pemberian pelayanan kepada konsumen, perusahaan juga jangan melupakan pesaingnya karena jika produk pesaingnya lebih diterima oleh masyarakat perusahaan tersebut akan kehilangan konsumen dan mengurangi pendapatan yang diterima.

\section{Faktor Internal Perusahaan}

Faktor-faktor yang menyebabkan kebangkrutan secara internal menurut Harnanto (dalam Adnan, 2000:140) sebagai berikut :

a. Terlalu besarnya kredit yang diberikan kepada nasabah sehingga akan menyebabkan adanya penunggakan dalam pembayaran sampai akhirnya tidak dapat membayar.

b. Manajemen tidak efisien yang disebabkan karena kurang adanya kemampuan, pengalaman, ketrampilan, sikap inisiatif dari manajemen.

c. Penyalahgunaan wewenang dan kecurangan dimana sering dilakukan oleh karyawan,bahkan manajer puncak sekalipun sangat merugikan apalagi yang berhubungan dengan keuangan perusahaan.

\section{Alternatif Perbaikan Kesulitan Keuangan}

Ada beberapa alternatif perbaikan kesulitan keuangan berdasarkan besar kecilnya permasalahan keuangan yang dihadapi oleh perusahaan (Hanafi dan Halim, 2005:274) :

\section{Pemecahan secara informal}

Pemecahan ini dilakukan apabila masalah masih belum parah. Masalah perusahaan hanya bersifat sementara, prospek masa depan masih bagus. Cara pemecahannya adalah sebagai berikut :

a. Perpanjangan (Extension) : dilakukan dengan memperpanjang jatuh tempo hutang.

b. Komposisi (Composition) : dilakukan dengan mengurangi besarnya tagihan.

c. Likuidasi : dapat dilakukan jika nilai likuidasi lebih besar dibandingkan nilai going concern.

\section{Pemecahan secara Formal}

Pemecahan ini dilakukan apabila masalah sudah parah, sehingga kreditur dan pemasok dana lainnya ingin mempunyai jaminan keamanan dan keadilan. Pemecahan secara formal melibatkan pihak ketiga yaitu pengadilan. Cara pemecahannya adalah sebagai berikut:

a. Apabila nilai perusahaan diteruskan > nilai perusahaan dilikuidasi, maka perusahaan mengambil langkah reorganisasi, yaitu dengan merubah struktur modal menjadi struktur modal yang layak. Perubahan bisa dilakukan melalui perpanjangan, dan perubahan komposisi, atau keduanya.

b. Apabila nilai persahaan diteruskan < nilai perusahaan dilikuidasi, maka perusahaan lebih baik mengambil langkah likuidasi, yaitu dengan menjual assetasset perusahaan, kemudian didistribusikan ke pemasok modal di bawah pengawasan pihak ketiga.

\section{Rasio-Rasio Z-Score}

Rasio-rasio dalam Z-Score ini masing-masing memberikan gambaran tersendiri mengenai perusahaan, yaitu:

Working Capital to Total Asset (Rasio Modal Kerja terhadap Total Aktiva) (X1)

Rasio pertama yang digunakan sebagai alat untuk memprediksi kebangkrutan adalah rasio modal kerja terhadap total aktiva. Rasio ini digunakan untuk mengukur likuiditas. Aktiva likuid bersih atau modal kerja bersih adalah selisih antara total aktiva lancar 
dikurangi total kewajiban lancar. Umumnya, bila perusahaan mengalami kesulitan keuangan, modal kerja akan turun lebih cepat daripada total aktiva menyebabkan rasio ini turun. Modal kerja bersih yang negative juga kemungkinan besar akan menghadapi masalah dalam menutupi kewajiban jangka pendeknya karena tidak tersedianya aktiva lancar yang cukup untuk menutupi kewajiban tesebut. Sebaliknya, perusahaan dengan modal kerja yang bernilai positif jarang sekali menghadapi kesulitan dalam melunasi kewajibannya. Rasio modal kerja menunjukkan jumlah modal kerja yang dimiliki pada setiap Rp 1,00 aktiva perusahaan.

Retained Earning to Total Assets (Rasio Laba Ditahan terhadap Total Aktiva) Retained Earning / Total Assets (X2)

Merupakan rasio profitabilitas yang menilai kemampuan perusahaan dalam menghasilkan laba selama masa operasi perusahaan. Umur perusahaan berpengaruh terhadap rasio tersebut karena semakin lama perusahaan beroperasi, memungkinkan untuk memperlancar akumulasi laba ditahan. Hal tersebut menyebabkan perusahaan yang masih relatif muda pada umumnya akan menunjukkan hasil rasio yang rendah, kecuali yang labanya sangat besar pada masa awal berdirinya. Semakin besar rasio ini, menunjukkan semakin besarnya peranan laba ditahan dalam membentuk dana perusahaan. Semakin kecil rasio ini menunjukkan kondisi keuangan perusahaan yang tidak sehat. Rasio laba ditahan terhadap total aktiva menunjukkan bahwa setiap Rp 1,00 aktiva perusahaan dijamin oleh saldo laba ditahan.

Earning Before Interest and Taxes to TotalAssets (Rasio EBIT terhadap Total Aktiva) (X3)

Rasio ini megukur kemampulabaan, yaitu tingkat pengembalian aktiva, yang dihitung dengan membagi laba sebelum bunga dan pajak (EBIT) tahunan perusahaan dengan total aktiva pada neraca akhir tahun. Rasio ini juga dapat digunakan sebagai ukuran sebarapa besar produktivitas penggunaan dana yang dipinjam. Rasio EBIT terhadap total aktiva menunjukkan laba bersih sebelum bunga dan pajak yang dapat dihasilkan dari setiap Rp 1,00 aktiva perusahaan.

Market Value Of Equity to Book Value Of Liabilities (Rasio Nilai Pasar Modal terhadap Total Hutang) (X4)

Rasio ini menunjukkan kemampuan perusahaan untuk memenuhi kewajibankewajiban jangka panjang dari nilai modal sendiri (saham biasa). Nilai pasar modal sendiri diperoleh dengan mengalikan jumlah lembar saham biasa yang beredar denganharga pasar per lembar saham biasa. Nilai buku hutang diperoleh dengan menjumlahkan kewajiban lancar dengan kewajiban jangka panjang. Semakin kecil rasio ini, menunjukkan kondisi keuangan peusahaan yang tidak sehat. Rasio nilai pasar modal sendiri terhadap nilai buku total kewajiban menunjukkan setiap Rp 1,00 dari total kewajiban digunakan untuk membiayai modal saham.

Sales to Total Assets (Rasio Penjualan terhadap Total Aktiva) (X5)

Rasio ini merupakan rasio aktivitas yang digunakan untuk mengukur kemampuan perusahaan dalam dalam meningkatkan volume penjualan. Rasio ini mencerminkan efisiensi manajemen dalam menggunakan keseluruhan aktiva perusahaan untuk menghasilkan penjualan dan mendapatkan laba. Semakin rendah rasio ini menunjukkan semakin rendah tingkat pendapatan perusahaan, sehingga menunjukkan kondisi keuangan perusahaan yang tidak sehat. Rasio penjualan terhadap total aktiva menunjukkan efektifitas penggunaan seluruh aktiva perusahaan dalam rangka menghasilkan penjualan bersih yang dapat dihasilkan oleh setiap $\mathrm{Rp} 1,00$ yang diinvestasikan dalam bentuk aktiva perusahaan. 


\section{Metoda Penelitian}

Jenis Penelitian ini menggunakan pendekatan kuantitatif yang merupakan masingmasing variabel maupun antar variabel didasari pada skala pengukuran kuantitatif.

Populasi dan sampel dalam penelitian ini di Bursa Efek Indonesia periode 2012-2016. Populasi dalam penelitian ini adalah Bank Pemerintah (BUMN) yang terdaftar di Bursa Efek Indonesia dari tahun 2012-2016 berdasarkan yang termuat dalam IDX periode tahun 2012-2016. dan situs internet www.idx.co.id.

Sampel Penelitian sbb :

\begin{tabular}{ccl}
\hline No. & Kode & \multicolumn{1}{c}{ Bank Pemerintah (BUMN) di Indonesia } \\
\hline 1 & BBNI & Bank Negara Indonesia (Persero) \\
2 & BMRI & Bank Mandiri (Persero) \\
3 & BBRI & Bank Rakyat Indonesia (Persero) \\
4 & BBTN & Bank Tabungan Negara (Persero) \\
\hline
\end{tabular}

Identifikasi variabel dan definisi operasional sbb :

\begin{tabular}{lcc}
\multicolumn{1}{c}{ Variable } & Proxy & Measurement \\
\hline $\begin{array}{l}\text { Rasio modal kerja terhadap total } \\
\text { aktiva }\end{array}$ & X1 & X1 $=\frac{\text { Modal Kerja }}{\text { Total Aktiva }}$ \\
$\begin{array}{l}\text { Rasio Laba Ditahan terhadap Total } \\
\text { Aktiva }\end{array}$ & X2 & X2 $=\frac{\text { Laba ditahan }}{\text { Total Aktiva }}$ \\
$\begin{array}{l}\text { Rasio Laba sebelum bunga dan } \\
\text { pajak terhadap total aktiva }\end{array}$ & X3 & X3 $=\frac{\text { EBIT }}{\text { Total Aktiva }}$ \\
$\begin{array}{l}\text { Nilai Pasar Modal Saham terhadap } \\
\text { Nilai Buku Hutang }\end{array}$ & X4 & X4 $=\frac{\text { Nilai Pasar Modal }}{\text { Nilai Buku Hutang }}$ \\
$\begin{array}{l}\text { Rasio Penjualan terhadap Total } \\
\text { aktiva }\end{array}$ & X5 & X5 $=\frac{\text { Penjualan }}{\text { Total Aktiva }}$ \\
\hline
\end{tabular}

\section{Teknik Analisis Data}

Analisis data yang digunakan dalam penilitian ini adalah analisis data kuantitatif yaitu suatu teknik analisis data dengan menganalisis menggunakan perhitungan angka-angka dari laporan keuangan, seperti neraca, laba rugi dan penjualan, yang kemudian digunakan sebagai dasar pengambilan keputusan. Teknik analisa yang digunakan dalam penilitian ini adalah sebagai berikut :

1. Menghitung beberapa rasio keuangan perusahaan yang terdapat dalam sampel penelitian ini,

2. Data atau hasil perhitungan rasio keuangan kemudian dianalisis dengan menggunakan formula yang ditemukan oleh Altman yaitu:

$\mathrm{Zi}=0,717 \mathrm{X} 1+0,847 \mathrm{X} 2+3,107 \mathrm{X} 3+0,420 \mathrm{X} 4+0,998 \times 5$

Dimana:

X1 = Rasio Modal kerja terhadap total aktiva

X2 = Rasio Laba Ditahan terhadap Total Aktiva 
X3 = Rasio Laba Sebelum Bunga dan Pajak terhadap Total Aktiva

X4 = Rasio Nilai Pasar Modal Saham terhadap Nilai Buku Hutang

X5 = Rasio Penjualan terhadap Total Aktiva

3. Mengklasifikasikan masing - masing sampel penelitian berdasarkan kriteria-kriteria kebangkrutan.

Kriteria-kriteria kebangkrutan menurut Altman adalah sebagai berikut:

\begin{tabular}{|c|c|c|}
\hline No. & Altman Z-Score & Predikat \\
\hline 1 & $\mathrm{Zi}>2,90$ & Sehat \\
\hline 2 & $\mathrm{Zi}$ diantara $1,20-2,90$ & Rawan Bangkrut (Grey Area / zone of ignorance) \\
\hline 3 & $\mathrm{Zi}<1,20$ & Bankrut \\
\hline
\end{tabular}

(Sumber : Hanafi dan Halim, 2005:274).

\section{Hasil dan Pembahasan}

\section{Perhitungan Analisis Altman Z-Score}

a. Bank Mandiri (Persero) Tbk.

Hasil perhitungan untuk nilai Z-Score Bank Mandiri (Persero) Tbk. pada periode 2012 sampai 2016 dapat terlihat pada tabel 1 sebagai berikut :

Tabel 1

Nilai $Z$ Score Bank Mandiri (Persero) Tbk.

Tahun 2012 - 2016

\begin{tabular}{|c|c|c|c|c|c|c|c|}
\hline \multirow{2}{*}{ Periode } & \multicolumn{5}{|c|}{ Nilai Z Score } & \multirow{2}{*}{$\mathbf{Z i}$} & \multirow{2}{*}{ Klasifikasi } \\
\hline & $\mathbf{X 1}$ & $\mathrm{X} 2$ & X3 & $\mathrm{X} 4$ & X5 & & \\
\hline 2012 & 0.120 & 0.072 & 0.025 & 2.698 & 0.047 & 2.963 & Sehat \\
\hline 2013 & 0.121 & 0.081 & 0.026 & 2.063 & 0.050 & 2.341 & Rawan Bangkrut \\
\hline 2014 & 0.123 & 0.087 & 0.024 & 2.398 & 0.049 & 2.680 & Rawan Bangkrut \\
\hline 2015 & 0.131 & 0.098 & 0.023 & 1.806 & 0.053 & 2.112 & Rawan Bangkrut \\
\hline 2016 & 0.148 & 0.093 & 0.014 & 1.761 & 0.052 & 2.069 & Rawan Bangkrut \\
\hline Rata-Rata & 0.129 & 0.086 & 0.022 & 2.145 & 0.050 & 2.433 & Rawan Bangkrut \\
\hline
\end{tabular}

Dari data di atas dapat diinterprestasikan sebagai berikut:

Selama 4 tahun dari tahun 2013 sampai 2016 berturut-turut Bank Mandiri (Persero) Tbk. berada di posisi rawan bangkrut atau bisa dikatakan perusahaan yang berpotensi kebangkrutan. Hal ini dapat dilihat pada nilai $\mathrm{Zi}$ yang berada diantara $1.20 \%$ $2.90 \%$. hanya tahun 2012 perusahaan ini dalam keadaan stabil. Hal ini dapat dilihat dari nilai $Z$-Score pada tahun tersebut sehat.

Penurunan $\mathrm{Zi}$ dari tahun ketahun pada perusahaan menunjukkan bahwa perusahaan harus memperbaiki kinerja keuangannya. sehingga secara keseluruhan Bank Mandiri (Persero) Tbk. bisa dikatakan Rawan Bangkrut.

Dari hasil perhitungan untuk nilai Z-Score Bank Mandiri (Persero) Tbk. pada periode 2012 sampai 2016 dapat digambarkan grafik yang terlihat pada gambar 1 berikut: 


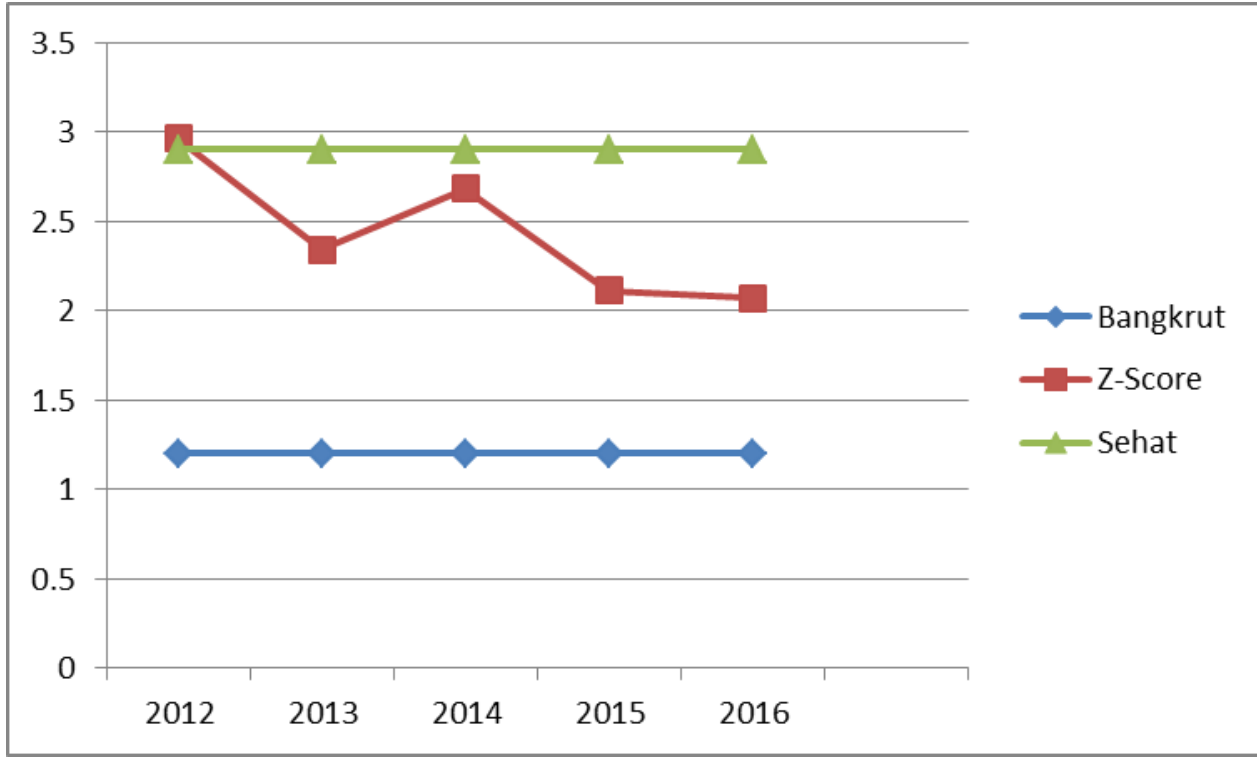

Gambar 1

Nilai Z-Score Bank Negara Indonesia (Persero)

\section{b. Bank Negara Indonesia (Persero) Tbk.}

Hasil perhitungan untuk nilai Z-Score Bank Negara Indonesia (Persero) Tbk. pada periode 2012 sampai 2016 dapat terlihat pada tabel 2 sebagai berikut :

Tabel 2

Nilai Z Score Bank Negara Indonesia (Persero) Tbk.

Tahun 2012 - 2016

\begin{tabular}{|c|c|c|c|c|c|c|c|}
\hline \multirow{2}{*}{ Periode } & \multicolumn{5}{|c|}{ Nilai Z Score } & \multirow{2}{*}{ Zi } & \multirow{2}{*}{ Klasifikasi } \\
\cline { 2 - 6 } & $\mathbf{X 1}$ & $\mathbf{X 2}$ & $\mathbf{X 3}$ & $\mathbf{X 4}$ & $\mathbf{X 5}$ & & \\
\hline 2012 & 0.131 & 0.060 & 0.021 & 1.521 & 0.068 & 1.801 & Rawan Bangkrut \\
\hline 2013 & 0.123 & 0.070 & 0.023 & 1.545 & 0.068 & 1.830 & Rawan Bangkrut \\
\hline 2014 & 0.146 & 0.084 & 0.029 & 1.864 & 0.054 & 2.177 & Rawan Bangkrut \\
\hline 2015 & 0.154 & 0.082 & 0.041 & 1.186 & 0.073 & 1.536 & Rawan Bangkrut \\
\hline 2016 & 0.148 & 0.084 & 0.020 & 1.154 & 0.073 & 1.480 & Rawan Bangkrut \\
\hline Rata-Rata & $\mathbf{0 . 1 4 1}$ & $\mathbf{0 . 0 7 6}$ & $\mathbf{0 . 0 2 7}$ & $\mathbf{1 . 4 5 4}$ & $\mathbf{0 . 0 6 7}$ & $\mathbf{1 . 7 6 5}$ & Rawan Bangkrut \\
\hline
\end{tabular}

Dari data di atas dapat diinterprestasikan sebagai berikut:

Sumber: Data diolah (2018)

Selama 5 tahun dari tahun 2012 sampai 2016 berturut-turut Bank Negara Indonesia (Persero) Tbk. berada di posisi rawan bangkrut atau bisa dikatakan perusahaan yang berpotensi kebangkrutan. Hal ini dapat dilihat pada nilai Zi yang berada diantara $1.20 \%-2.90 \%$.

Peningkatan $\mathrm{Zi}$ dari tahun ketahun pada perusahaan menunjukkan bahwa perusahaan sedang memperbaiki kinerja keuangannya. Diperkirakan di tahun yang akan dating perusahaan dapat berada di posisi sehat apabila perusahaan terus meningkatkan kinerjanya..

Peningkatan $\mathrm{Zi}$ dari tahun ketahun pada perusahaan menunjukkan bahwa perusahaan harus memperbaiki kinerja keuangannya. sehingga secara keseluruhan Bank Negara Indonesia (Persero) Tbk. bisa dikatakan Rawan Bangkrut.

Dari hasil perhitungan untuk nilai Z-Score Bank Negara Indonesia (Persero) Tbk. pada periode 2012 sampai 2016 dapat digambarkan grafik yang terlihat pada gambar 2 berikut: 


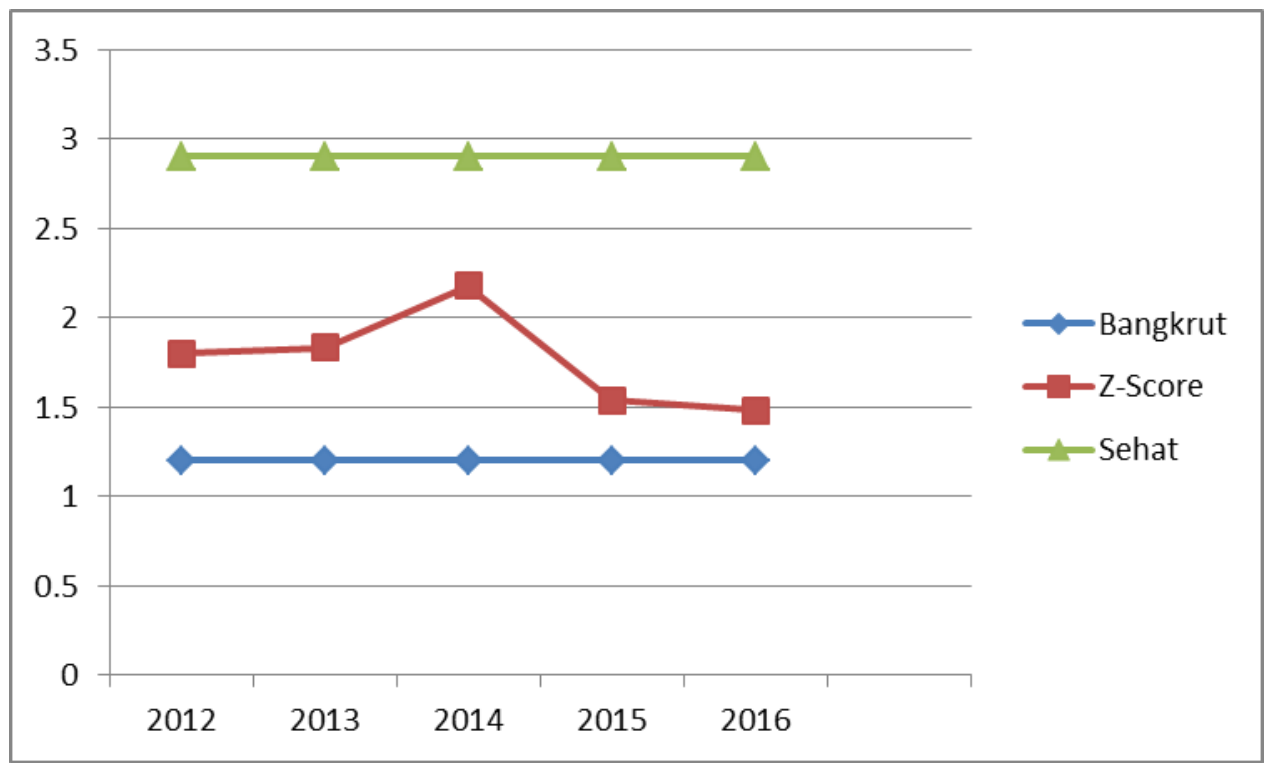

Gambar 2

Nilai Z-Score Bank Negara Indonesia (Persero) Tbk.

\section{c. Bank Rakyat Indonesia (Persero) Tbk.}

Hasil perhitungan untuk nilai Z-Score Bank Rakyat Indonesia (Persero) Tbk. pada periode 2012 sampai 2016 dapat terlihat pada tabel 3 sebagai berikut :

Tabel 3

Nilai Z Score Bank Rakyat Indonesia (Persero) Tbk.

Tahun 2012 - 2016

\begin{tabular}{|c|c|c|c|c|c|c|c|}
\hline \multirow{2}{*}{ Periode } & \multicolumn{5}{|c|}{ Nilai Z Score } & \multirow{2}{*}{ Zi } & \multirow{2}{*}{ Klasifikasi } \\
\cline { 2 - 6 } & $\mathbf{X 1}$ & $\mathbf{X 2}$ & $\mathbf{X 3}$ & $\mathbf{X 4}$ & $\mathbf{X 5}$ & & Sehat \\
\hline 2012 & 0.118 & 0.100 & 0.034 & 2.871 & 0.088 & 3.210 & Sehat \\
\hline 2013 & 0.127 & 0.113 & 0.034 & 2.255 & 0.092 & 2.621 & Rawan Bangkrut \\
\hline 2014 & 0.122 & 0.111 & 0.030 & 2.940 & 0.091 & 3.294 & Rawan Bangkrut \\
\hline 2015 & 0.129 & 0.122 & 0.029 & 2.491 & 0.094 & 2.865 & Ran \\
\hline 2016 & 0.146 & 0.125 & 0.026 & 1.962 & 0.092 & 2.351 & Rawan Bangkrut \\
\hline Rata-Rata & $\mathbf{0 . 1 2 8}$ & $\mathbf{0 . 1 1 4}$ & $\mathbf{0 . 0 3 1}$ & $\mathbf{2 . 5 0 4}$ & $\mathbf{0 . 0 9 1}$ & $\mathbf{2 . 8 6 8}$ & Rawan Bangkrut \\
\hline
\end{tabular}

Sumber: Data diolah (2018)

Dari data di atas dapat diinterprestasikan sebagai berikut:

Selama 2 tahun dari tahun 2015 sampai 2016 berturut-turut Bank Rakyat Indonesia (Persero) Tbk. berada di posisi rawan bangkrut atau bisa dikatakan perusahaan yang berpotensi kebangkrutan. Hal ini dapat dilihat pada nilai Zi yang berada diantara 1.20\%-2.90\%. hanya saja pada tahun 2012 dan tahun 2014 Bank BRI dikatakan sehat.

Penurunan Zi dari 2 tahun terakhir pada Bank Rakyat Indonesia (Persero) Tbk. menunjukkan bahwa bank BRI sedang ada masalah kinerja keuangannya sehingga secara keseluruhan Bank Rakyat Indonesia (Persero) Tbk. bisa dikatakan Rawan Bangkrut.

Dari hasil perhitungan untuk nilai Z-Score Bank Rakyat Indonesia (Persero) Tbk. pada periode 2012 sampai 2016 dapat digambarkan grafik yang terlihat pada gambar 3 berikut: 


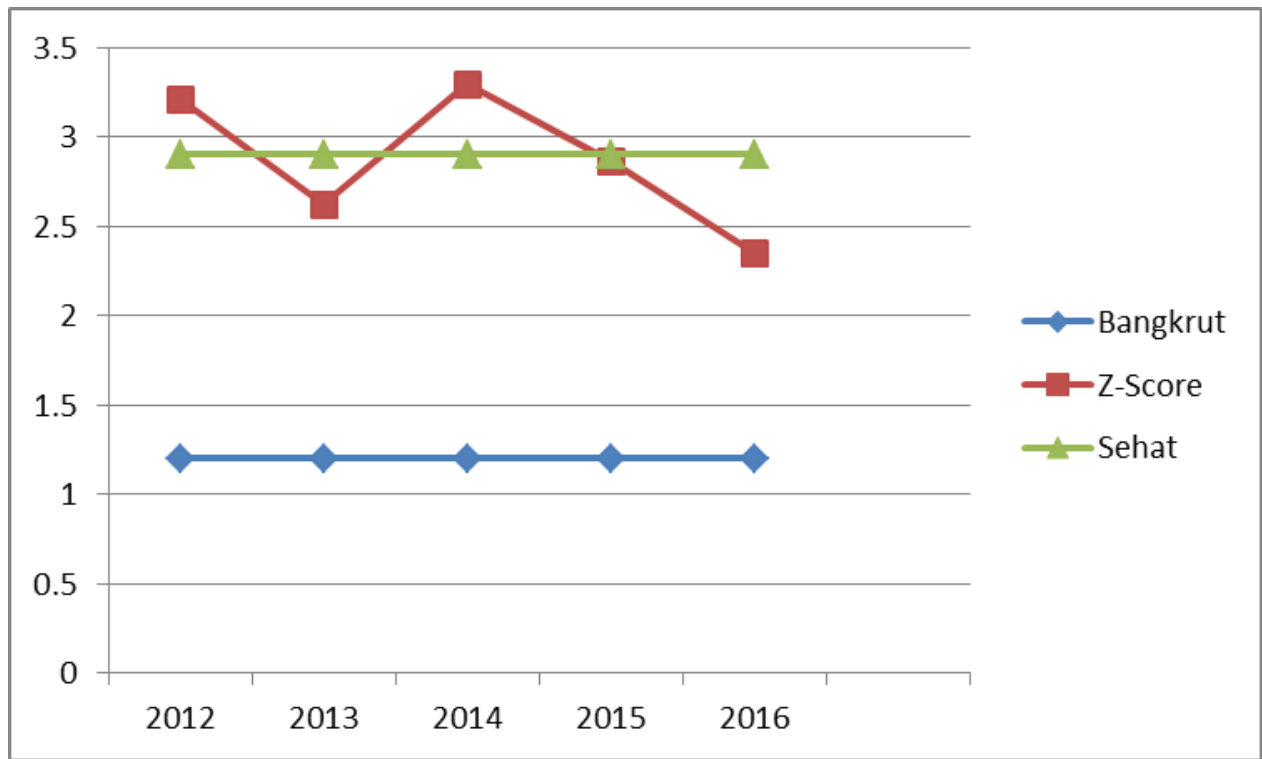

Gambar 3

Nilai Z-Score Bank Rakyat Indonesia (Persero) Tbk.

\section{d. Bank Tabungan Negara (Persero) Tbk.}

Hasil perhitungan untuk nilai Z-Score Bank Tabungan Negara (Persero) Tbk. pada periode 2012 sampai 2016 dapat terlihat pada tabel 3 sebagai berikut :

Tabel 4

Nilai Z Score Bank Tabungan Negara (Persero) Tbk.

Tahun 2012 - 2016

\begin{tabular}{|c|c|c|c|c|c|c|c|}
\hline \multirow{2}{*}{ Periode } & \multicolumn{5}{|c|}{ Nilai Z Score } & \multirow{2}{*}{ Zi } & \multirow{2}{*}{ Klasifikasi } \\
\cline { 2 - 6 } & $\mathbf{X 1}$ & $\mathbf{X 2}$ & $\mathbf{X 3}$ & $\mathbf{X 4}$ & $\mathbf{X 5}$ & & \\
\hline 2012 & 0.092 & 0.028 & 0.012 & 0.856 & 0.079 & 1.068 & Bangkrut \\
\hline 2013 & 0.088 & 0.033 & 0.012 & 0.795 & 0.082 & 1.011 & Bangkrut \\
\hline 2014 & 0.084 & 0.035 & 0.008 & 1.039 & 0.089 & 1.255 & Rawan Bangkrut \\
\hline 2015 & 0.081 & 0.288 & 0.011 & 0.989 & 0.087 & 1.456 & Rawan Bangkrut \\
\hline 2016 & 0.089 & 0.042 & 0.012 & 0.385 & 0.080 & 0.609 & Bangkrut \\
\hline Rata-Rata & $\mathbf{0 . 0 8 7}$ & $\mathbf{0 . 0 8 5}$ & $\mathbf{0 . 0 1 1}$ & $\mathbf{0 . 8 1 3}$ & $\mathbf{0 . 0 8 3}$ & $\mathbf{1 . 0 8 0}$ & Bangkrut \\
\hline
\end{tabular}

Dari data di atas dapat diinterprestasikan sebagai berikut:

Sumber: Data diolah (2018)

Selama 3 tahun yaitu tahun 2012 dan 2013 serta 2016 Bank Tabungan Negara (Persero) Tbk. berada di katagori bangkrut atau bisa dikatakan perusahaan yang kebangkrutan karena kurang dari 1.20\%. Dan pada tahun 2014 dan tahun 2015 dikatakan Rawan Bangkrut ini dapat dilihat pada nilai Zi yang berada diantara $1.20 \%-2.90 \%$.

Penurunan Zi dari 5 tahun terakhir pada Bank Rakyat Indonesia (Persero) Tbk. menunjukkan bahwa bank BTN sedang ada masalah kinerja keuangannya sehingga secara keseluruhan Bank Tabungan Negara (Persero) Tbk. bisa dikatakan Bangkrut.

Dari hasil perhitungan untuk nilai Z-Score Bank Tabungan Negara (Persero) Tbk. pada periode 2012 sampai 2016 dapat digambarkan grafik yang terlihat pada gambar 4 berikut: 


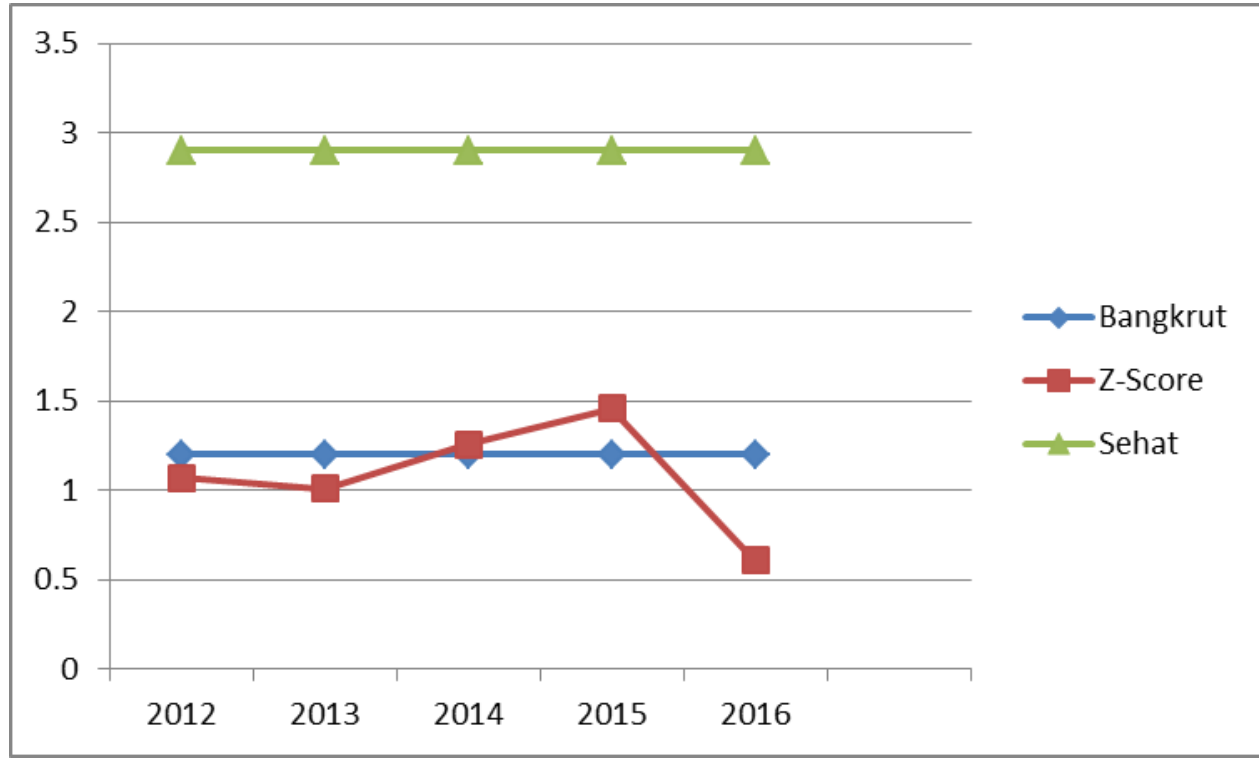

Gambar 4

Nilai Z-Score Bank Tabungan Negara (Persero) Tbk.

\section{Analisa Altman Z-Score untuk Memprediksi Kebangkrutan pada Bank Pemerintah (BUMN) di Indonesia tahun 2012-2016}

Hasil Altman Z-Score Bank Pemerintah (BUMN) di Indonesia tahun 2012-2016 Tabel 5 menunjukkan bahwa rata-rata Kebangkrutan pada Bank Pemerintah (BUMN) di Indonesia terdaftar di Bursa Efek Indonesia (BEI) sebagai berikut :

Tabel 5

Kebangkrutan pada Bank Pemerintah (BUMN) di Indonesia tahun 2012-2016

\begin{tabular}{|c|c|c|c|c|c|c|c|c|}
\hline \multirow{2}{*}{ No } & \multirow{2}{*}{$\begin{array}{c}\text { Nama Bank } \\
\text { Pemerintah } \\
\text { (BUMN) }\end{array}$} & \multicolumn{5}{|c|}{ Analisa Altman Z-Score } & \multirow{2}{*}{ Rata $^{2}$} & \multirow{2}{*}{ Kriteria } \\
\hline & & 2012 & 2013 & 2014 & 2015 & 2016 & & \\
\hline 1 & $\begin{array}{l}\text { Bank Negara } \\
\text { Indonesia(Persero) }\end{array}$ & 0.129 & 0.086 & 0.022 & 2.145 & 0.050 & 2.433 & $\begin{array}{c}\text { Rawan } \\
\text { Bangkrut }\end{array}$ \\
\hline 2 & $\begin{array}{l}\text { Bank Mandiri } \\
\text { (Persero) }\end{array}$ & 0.141 & 0.076 & 0.027 & 1.454 & 0.067 & 1.765 & $\begin{array}{l}\text { Rawan } \\
\text { Bangkrut }\end{array}$ \\
\hline 3 & $\begin{array}{l}\text { Bank Rakyat } \\
\text { Indonesia(Persero) }\end{array}$ & 0.128 & 0.114 & 0.031 & 2.504 & 0.091 & 2.868 & $\begin{array}{c}\text { Rawan } \\
\text { Bangkrut }\end{array}$ \\
\hline 4 & $\begin{array}{l}\text { Bank Tabungan } \\
\text { Negara (Persero) }\end{array}$ & 0.087 & 0.085 & 0.011 & 0.813 & 0.083 & 1.080 & Bangkrut \\
\hline \multicolumn{7}{|c|}{ Tingkat Kebangkrutan Bank Pemerintah (BUMN) } & 2.036 & $\begin{array}{c}\text { Rawan } \\
\text { Bangkrut }\end{array}$ \\
\hline
\end{tabular}

Sumber: Data diolah (2018)

Setelah dilakukan perhitungan terhadap masing-masing variabel $(X 1, X 2, X 3, X 4, X 5)$ dalam empat tahun berturut-turut sehingga dapat diketahui rata-rata Z-Score pada Bank Pemerintah (BUMN) di Indonesia sebesar 2.036, Hal ini menunujukkan bahwa kondisi Bank Pemerintah (BUMN) di Indonesia secara keseluruhan tidak berpotensi kebangkrutan dan Rawan Bangkrut.

Terdapat tiga perusahaan yang masuk dalam kategori rawan bangkrut atau bisa dikatakan Bank Pemerintah (BUMN) yang berpotensi kebangkrutan, yakni Bank Negara Indonesia (Persero), Bank Mandiri (Persero), Bank Rakyat Indonesia (Persero) dan satu 
prusahaan bias dikatakan bankrupt atau berpotensi bangkrut yaitu Bank Tabungan Negara (Persero).

Keempat perusahaan ini selama 3 tahun berturut-turut diprediksikan berpotensi bangkrut. Hal ini menunjukkan bahwa perusahaan harus lebih memfokuskan pada usaha perbaikan kinerja perusahaan untuk meningkatkan kelima rasio tersebut, misalnya yaitu dengan meningkatkan volume penjualan terhadap persediaan yang ada, sehingga ada pemasukan pada kas perusahaan dari hasil penjualan tersebut. Selain memperbaiki dari segi keuangan perusahaan namun perusahaan juga dapat dengan memperbaiki dan menambah asset tidak berwujud (Intangible Assets) yang dimiliki oleh perusahaan. Intangible Assets ini diantaranya adalah sistem manajemen perusahaan, pinjaman (Loan) dari pihak kedua baik bank maupun perusahaan lain, bantuan dari pemerintah (subsidiary), perjanjian kontrak kerjasama dengan perusahaan ternama. Melihat kondisi diatas, maka pengelola harus lebih berhati-hati dan harus melakukan perbaikan secepatnya.

\section{E. Kesimpulan dan Saran}

\section{Kesimpulan}

Berdasarkan Altman Z-Score untuk memprediksi kebangkrutan pada Bank Pemerintah (BUMN) di Indonesia tahun 2012-2016 sebagai berikut :

a) Analisis Altman Z-Score untuk memprediksi kebangkrutan pada Bank Mandiri (Persero) Tbk. dengan nilai rata-rata $\mathbf{2 . 4 3 3}$ berada di posisi Rawan Bangkrut atau bisa dikatakan perusahaan yang berpotensi kebangkrutan. Hal ini dapat dilihat pada nilai Zi yang berada diantara $1.20 \%-2.90 \%$.

b) Analisis Altman Z-Score untuk memprediksi kebangkrutan pada Bank Negara Indonesia (Persero) Tbk. dengan nilai rata-rata 1.765 berada di posisi Rawan Bangkrut atau bisa dikatakan perusahaan yang berpotensi kebangkrutan. Hal ini dapat dilihat pada nilai Zi yang berada diantara 1.20\%-2.90\%.

c) Analisis Altman Z-Score untuk memprediksi kebangkrutan pada Bank Rakyat Indonesia (Persero) Tbk. dengan nilai rata-rata 2.868 berada di posisi Rawan Bangkrut atau bisa dikatakan perusahaan yang berpotensi kebangkrutan. Hal ini dapat dilihat pada nilai Zi yang berada diantara 1.20\%-2.90\%.

d) Analisis Altman Z-Score untuk memprediksi kebangkrutan pada Bank Tabungan Negara (Persero) Tbk. dengan nilai rata-rata 1.080 berada di posisi Bangkrut atau bisa dikatakan perusahaan yang berpotensi kebangkrutan. Hal ini dapat dilihat pada nilai Zi yang kurang dari $1.20 \%$

e) Analisis Altman Z-Score untuk memprediksi kebangkrutan Bank Pemerintah (BUMN) di Indonesia tahun 2012-2016 dengan nilai rata-rata 2.036 berada di posisi Rawan Bangkrut atau bisa dikatakan perusahaan yang berpotensi kebangkrutan. Hal ini dapat dilihat pada nilai Zi yang berada diantara $1.20 \%-2.90 \%$. berdasarkan Altman Z-Score dalam Hanafi dan Halim, 2005:274.

\section{Saran}

Adapun saran yang dapat diberikan oleh peneliti atas penelitian yang telah dilakukan adalah sebagai berikut: Perusahaan dalam kategori ini harus lebih memfokuskan pada usaha perbaikan kinerja perusahaan untuk meningkatkan kelima rasio tersebut, misalnya yaitu dengan meningkatkan volume penjualan terhadap persediaan yang ada, sehingga ada pemasukan pada kas perusahaan dari hasil penjualan tersebut. Perusahaan yang berada dalam kondisi rawan bangkrut maka pengelola harus lebih berhati-hati dan harus melakukan perbaikan secepatnya agar tidak mengalami kebangkrutan di periode berikutnya. 


\section{Keterbatasan}

Keterbatasan dalam penelitian ini adalah bahwa analisis ini hanyalah bersifat "prediksi" atau ramalan keuangan perusahaan sehingga nilai $\mathrm{Zi}$ ini tidak bisa dijadikan tolok ukur dalam penentuan apakah perusahaan tersebut akan benar-benar bangkrut ataupun tidak bangkrut, karena manajemen harusmelihat dari segi indikator-indikator kegagalan perusahaan. Selain itu juga model diskriminan kebangkrutan yang dikembangkan oleh Altman ini didalamnya terdapat variabel-variabel yang diambil dari laporan keuangan sehingga jika penyusunan laporan keuangan terdapat kesalahan maka hasil dari nilai $Z i$ ini juga tidak akan akurat lagi.

\section{F. Daftar Pustaka}

Altman, E. I. 1968. Financial Ratios, Discriminant Analysis and the Prediction of Corporate

Adnan, K. M. dan E. Kurnayasih. 2000. Analisis Tingkat Kesehatan Perusahaan untuk Memprediksi Potensi Kebangkrutan pada Pendekatan Altman. Jurnal Akuntansi dan auditing Indonesia 4(2): 131-149. Bankcrupty. Journal of Finance 23 (4): 589-609.

Brigham \& Houston. (2010) Dasar - Dasar Manajemen Keuangan (Essentials Of Financial Management). Edisi ke - 11. Salemba Empat. Jakarta. (Diterjemahkan oleh Ali Akbar Yulianto).

Ferbianasari, H. N. 2011. Analisis Penilaian Financial Distress Menggunakan Model Altman (Z-Score) Pada Perusahaan Kosmetik Yang Tercatat Di Bursa Efek Indonesia. Skripsi.

Fakultas Ekonomi Universitas Negeri Surabaya. Surabaya.

Foster, G. 1986. Financial Statement Analysis. 2nd ed. Prentice Hall Int.Inc. USA.

Hanafi, M. M. dan A. Halim. 2005. Analisis Laporan Keuangan. AMP-YKPN. Yogyakarta.

Husaini Usman. (2008). Manjemen,Teori, Praktek dan Riset Pendidikan. Bumi Aksara, Jakarta.

Hanafi, M. M. (2008). Manajemen Keuangan. Edisi kesatu. BPFE-Yogyakarta. Yogyakarta.

Nardi Sunardi (2017), “Determinant Of Leverage And It's Implication On Company Value Of Real Estate And Property Sector Listing In IDX Period Of 2011-2015", International journal terindex scorpus, Man In India(MII) , 97 (24) : 131-148, ISSN : 0025-1569. September 2017.

Nardi Sunardi (2017), "Analisis CAMEL dalam Menilai Tingkat Kesehatan Bank (Studi Kasus pada Subsector Perbankan yang Terdaftar di BEI Priode 2011-2015)", Jurnal IImiah Inovasi ISSN No.2356-2005, Vol. IV, No.1, Juni 2017, Hal. 44-58. 
Peter dan Yoseph. (2011). Analisis kebangkrutan dengan Metode z-score Altman, Springate dan Zmijewski pada PT. Indofood Sukses Makmur Tbk Periode 2005 2009. Akurat Jurnal IImiah Akuntansi 2(4).

Sugiyono. 2010. Metode Penelitian Bisnis. Cetakan ketiga. Alfabeta. Bandung.

Sopiyah Arini dan Triyonowati, (2013), "Analisis Altman Z-Score Untuk Memprediksi Kebangkrutan Pada Perusahaan Farmasi di Indonesia", Jurnal IImu \& Riset Manajemen Vol. 2 No. 11 (2013), Sekolah Tinggi Ilmu Ekonomi Indonesia (STIESIA) Surabaya.

Suci Kurniawati (2016), "Analisis Kebangkrutan dengan Model Altman Z-Score Pada Perusahaan Subsektor Logam \& Sejenisnya di BEI Periode 2014", Seminar Nasional Cendekiawan 2016, Sekolah Tinggi IImu Ekonomi Indonesia Rawamangun.

Gilrita, Moch. Dzulkirom dan M.G Wi Endang N.P (2015), "Analisis Altman (Z-Score) Sebagai Salah Satu Cara untuk Mengukur Potensi Kebangkrutan Perusahaan (Studi Pada Perusahaan Manufaktur yang Listing di BEI dan Perusahaan Manufaktur yang Delisting dari BEI Periode 2012-2014)", Jurnal Administrasi Bisnis (JAB) Vol. 25 No. 1 Agustus 2015, Fakultas IImu Administrasi, Universitas Brawijaya. 